\title{
Narrow-band imaging does not improve detection of colorectal polyps when compared to conventional colonoscopy: a randomized controlled trial and meta-analysis of published studies
}

\author{
Luis C Sabbagh ${ }^{*}$, Ludovic Reveiz ${ }^{2}$, Diego Aponte ${ }^{3}$ and Sylvia de Aguiar ${ }^{4}$
}

\begin{abstract}
Background: A colonoscopy may frequently miss polyps and cancers. A number of techniques have emerged to improve visualization and to reduce the rate of adenoma miss.

Methods: We conducted a randomized controlled trial (RCT) in two clinics of the Gastrointestinal Department of the Sanitas University Foundation in Bogota, Colombia. Eligible adult patients presenting for screening or diagnostic elective colonoscopy were randomlsy allocated to undergo conventional colonoscopy or narrow-band imaging (NBI) during instrument withdrawal by three experienced endoscopists. For the systematic review, studies were identified from the Cochrane Library, PUBMED and LILACS and assessed using the Cochrane risk of bias tool.

Results: We enrolled a total of 482 patients (62.5\% female), with a mean age of 58.33 years (SD 12.91); 241 into the intervention (NBI) colonoscopy and 241 into the conventional colonoscopy group. Most patients presented for diagnostic colonoscopy (75.3\%). The overall rate of polyp detection was significantly higher in the conventional group compared to the NBI group (RR $0.75,95 \% \mathrm{Cl} 0.60$ to 0.96 ). However, no significant differences were found in the mean number of polyps (MD $-0.1 ; 95 \% \mathrm{Cl}-0.25$ to 0.05 ), and the mean number of adenomas (MD $0.0495 \% \mathrm{Cl}$ -0.09 to 0.17 ). Meta-analysis of studies (regardless of indication) did not find any significant differences in the mean number of polyps (5 RCT, 2479 participants; WMD $-0.0795 \% \mathrm{Cl}-0.21$ to $0.07 ; 1268 \%$ ), the mean number of adenomas (8 RCT, 3517 participants; WMD $-0.0895 \% \mathrm{Cl}-0.17 ; 0.01$ to 12 62\%) and the rate of patients with at least one adenoma (8 RCT, 3512 participants, RR $0.9695 \%$ Cl 0.88 to 1,04;12 0\%).
\end{abstract}

Conclusion: NBI does not improve detection of colorectal polyps when compared to conventional colonoscopy (Australian New Zealand Clinical Trials Registry ACTRN12610000456055).

Keywords: Randomized controlled trial, colonoscopy, polyps, narrow-band imaging

\section{Background}

Screening for colorectal cancer using fecal occult blood testing, sigmoidoscopy, or colonoscopy is recommended in several countries in people above 50 years of age with an average risk and earlier in people with a strong family history or other risk factors [1-3]. Adenomatous

\footnotetext{
* Correspondence: Isabbagh@colsanitas.com

'Gastroenterology Department, Clínica Reina Sofía, Sanitas University

Foundation, Bogota, Colombia

Full list of author information is available at the end of the article
}

polyps are deemed to be precursors of colorectal cancer. Some studies have shown that removal of polyps and postpolypectomy surveillance decreases the incidence of colorectal cancer [1,4-6].

Colonoscopy is considered to be the reference standard against which the sensitivity of other colorectal cancer screening tests is compared [1-3]. However, assessing the sensitivity and specificity of colonoscopy by comparing colonoscopy versus tandem colonoscopies, CT colonography and colonic specimens showed that

\section{C) Biomed Central}


colonoscopy may frequently miss polyps and cancers [7-9]. Meta-analysis of six studies [7] found that the miss rate for polyps of any size was 22\% (95\% CI: 19 to $26 \%$ ). The study also reported that the adenoma miss rate was $2.1 \%, 13 \%$, and $26 \%$ for polyp sizes of $10 \mathrm{~mm}$ and higher, 5-10 $\mathrm{mm}$ and 1-5 $\mathrm{mm}$ respectively. In another study, the diameter and the number of polyps $(\geq 3)$ were independently associated with a lower polyp miss rate, whereas sessile or flat shape was significantly associated with a higher miss rate [8]. Simmons et al. analyzed 10,955 colonoscopies performed by 43 endoscopists and found that longer withdrawal time was also associated with higher polyp detection rate, particularly for smaller polyps [10]. Another study found that most advanced adenomas (74\%) and cancers (95\%) were detected during the insertion [11].

Diverse reasons for the miss rate have been suggested, including incomplete colonoscopy, the quality of bowel preparation, lesion characteristics (location, number, shape and size), the endoscopist's experience, the operator's insertion and the withdrawal technique [8-12].

A number of techniques have emerged to improve visualization and to reduce the adenoma miss rate [13]. The narrow-band imaging (NBI) technology in conventional video colonoscopes uses special filters to narrow a light source, eliminating red, enhancing structures and rendering vascular structures in black [14-18]. During the conduction of this research, a number of other studies comparing the NBI technique with conventional colonoscopy have been published [19-34].

The objective of this randomized controlled trial (RCT) was to evaluate the effectiveness of NBI during colonoscopy withdrawal compared to the conventional procedure in detecting polyps and adenomas. The objective of the systematic review was to identify and evaluate all RCT that assessed the effectiveness of diagnostic and screening conventional colonoscopy compared to NBI colonoscopy in detecting polyps and adenomas.

\section{Methods}

This open-label randomized controlled trial (RCT) was conducted at the Gastrointestinal Department of two private clinics (Clinica Reina Sofia and Clinica Colombia), both tertiary care referral centers, during a ninemonth study period. All consecutive adult patients presenting for screening or diagnostic colonoscopy for a variety of indications (e.g. positive fecal occult blood test, abdominal pain, post-polypectomy surveillance, diarrhea) were eligible for the RCT. Patients were excluded if they had known colonic neoplasia, inflammatory or another significant colonic disease (e.g. fulminant colitis, documented acute diverticulitis); if they had previously undergone colorectal surgery; if they had had a previous colonoscopy in the last 12 months before enrollment; if there was known familial adenomatous polyposis; if they were specifically presenting for polypectomy or emergency colonoscopy; if they were receiving anticoagulant medication; when adequate patient cooperation or consent could not be obtained; if the patient had a contraindication for the procedure; and in the cases of poor bowel preparation; active bleeding; or pregnancy. The trial protocol was approved by the Institutional Review Board of the Research Institute of the Medical School of the Sanitas University Foundation; written and informed consent was obtained from all the patients enrolled in the study. The study was registered in the Australian New Zealand Clinical Trials Registry ACTRN12610000456055.

\section{Assignment to interventions}

During the first part of the procedure, the colonoscope was inserted through the rectum and advanced to the large intestine using conventional colonoscopy in both groups (we did not use chromoendoscopy during the process of conventional colonoscopy observation). Thereafter, patients were randomly assigned to colonoscope withdrawal using either conventional wide-angle or NBI wide-angle colonoscopy (Olympus Corp: Olympus 180, CF-Q180AL\#2) in examinations conducted by a total of three experienced examiners (each with over 5,000 colonoscopies performed and more than 15 years of experience, including a minimum of two years of experience with NBI colonoscopy). The colonoscopies were performed using high definition monitors. Appropriate and complete bowel preparation before colonoscopy was ensured using four liters of polyethylene glycol lavage until clear rectal fluid was evacuated and a cleaning enema. We categorized the quality of bowel preparation into excellent, good, fair, poor or inadequate.

Randomization was performed in blocks of 4 and 6 using a random table. Once the caecum had been reached and appropriate bowel preparation confirmed, an opaque sealed envelope with sequential numbering was opened and participants were allocated to either NBI or conventional colonoscopy withdrawal of the instrument.

Polypectomies were performed in the same session during withdrawal when possible. Polyps were removed using snare polypectomy or forceps biopsy, depending on the size of the polyps.

\section{Outcome measures \\ Baseline Characteristics}

The following demographic data and medical history information were obtained before randomization for every eligible patient: gender, age, weight, height, indication for colonoscopy, previous colonoscopy, date of last 
colonoscopy, previous polyp resection, and familial history of colorectal cancer.

\section{Primary outcome measure}

1. Mean number of detected polyps and adenomas

2. Total number of polyps

\section{Secondary outcome measure}

1. Polyp detection rate (at least one polyp per patient)

2. Polyp size

3. Location

4. Total number of adenomas smaller than $5 \mathrm{~mm}$

5 . Time before finding the first polyp.

6. Final histological result. Histological studies were performed on all removed polyps.

7. Adverse events

\section{Sample size determination}

The primary endpoint for this study was the mean number of detected polyps. We assumed from institutional data that the mean number of polyps per patient in the control group would be 0.32 , with a standard deviation (SD) of 0.31. A clinically significant increase in polyp detection using the NBI system was determined to be $25 \%$. Using a two-tail alpha error of 0.05 , and beta error of 0.20 (power $>80 \%$ ), 240 patients in each arm would be required to detect a difference.

\section{Data management and analysis}

The database, created in Excel, was double-checked and transferred to SPSS $15.0^{\circ}$. Categorical variables were compared using the chi-square test. To evaluate the continuous variables, Student's t-test was used; $\mathrm{P}<0.05$ was considered statistically significant. The measurement of the intervention effect for dichotomous outcomes was the risk ratio (RR). The measurement of the intervention effect for continuous outcomes was assessed by the mean difference (MD).

\section{Systematic review of the current evidence}

During the conduction of this study, a number of other RCTs comparing the NBI technique with conventional colonoscopy were published. We performed an advanced search strategy of studies comparing the conventional colonoscopy to NBI to detect colorectal polyps/adenomas (appendix 1). Relevant RCTs were identified from the Cochrane Library (2009, Issue 4), PUBMED (1966-December 2009), LILACS (1982December 2009) and Scirus (http://www.scirus.com; December 2009). We also scanned bibliographies of relevant studies for possible references to additional RCT. Two authors independently decided which trials fit the inclusion criteria. Eligible RCT were included regardless of the language of publication. Two reviewers independently extracted the relevant data using a predesigned data extraction form and any disagreement was resolved by consensus with all authors. We extracted year of publication; patient population; number of patients (by intention to treat); sociodemographics; endoscopic, and histologic outcomes; and adverse effects. The main outcomes considered were the mean number of polyps, the mean number of adenomas and the rate of patients with at least one adenoma.

A risk of bias evaluation of each RCT was done following the Cochrane Collaboration's tool for the assessment of these features [35]. To estimate differences between treatments we calculated a weighted treatment effect across RCTs. We expressed the results as risk ratio (RR) with 95\% confidence intervals (CI) for dichotomous outcomes and weighted mean difference (WMD) with $95 \%$ CI for continuous outcomes. We imputed conservative standard deviations where necessary using the p-value from an independent two-sample t-test [35]. For the pooled analysis, we calculated the I2 statistic, which describes the percentage of total variation across studies caused by heterogeneity [35].

\section{Results}

\section{Randomized Controlled Trial}

Patients were enrolled during a three month period at the Reina Sofia Clinic and during a 2 month period at the Clinica Colombia, between September 2008 and May 2009. We included a total of 482 patients $(62.5 \%$ female), with a mean age of 58.33 years (SD 12.91); 241 into the intervention (NBI) colonoscopy and 241 into the conventional colonoscopy group. Patients were enrolled during a three month period at the Reina Sofia Clinic and during a 2 month period at the Clinica Colombia.

The flow of participants through each stage of the randomized trial is described in Figure 1. Most polyps (67\%) were found in the left colon; no significant difference was found between groups with regards to the location of the polyps. The total examination time did not differ significantly between the two groups $(9.21$ vs. 9.22; excluding polypectomy duration). Baseline characteristics of patients were similar among groups (Table 1).

The overall polyp detection rate per patient by visual inspection in the entire study group was $37.14 \%$ (77 polyps in the NBI group versus 102 in the conventional group). There was no protocol deviation, however $2.8 \%$ of visualized polyps were not available for histological analysis because polypectomy was delayed and no further procedure was performed until the termination of the study (Table 2).

No significant difference was found in the mean number of polyps when comparing the conventional procedure to the NBI system (0.41 vs. 0.29). The overall detection rate of lesions $(\mathrm{n}=174)$ and polyps $(\mathrm{n}=169)$ 


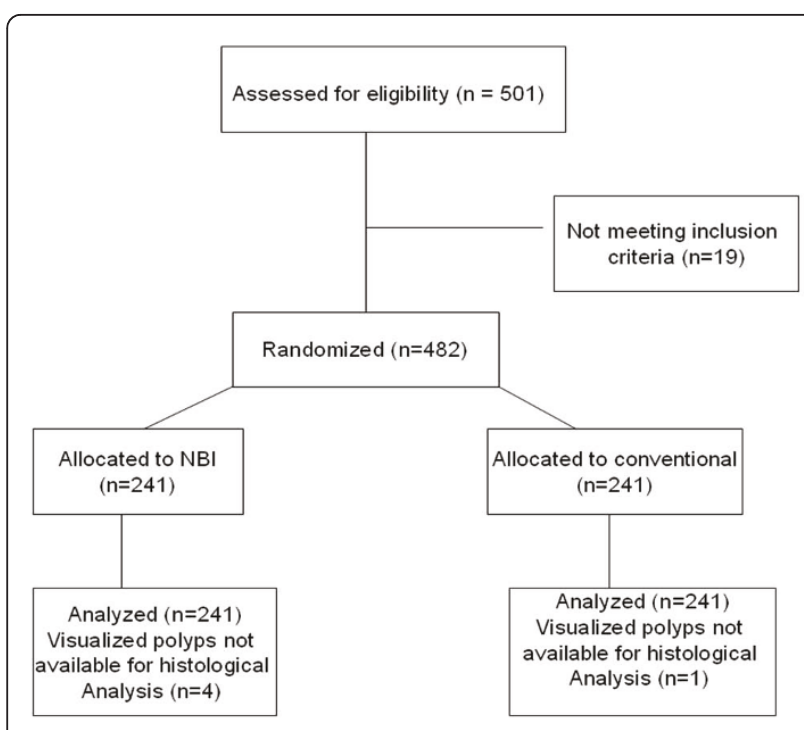

Figure 1 Flow of participants through each stage of the randomized trial.

by histological examination per patient in the entire study group were $36.1 \%$ and $35.1 \%$ respectively, with adenomas and hyperplastic polyps found, respectively, in $55.0 \%(\mathrm{n}=93 / 169)$ and $37.9 \%(\mathrm{n}=64 / 169)$ of all patients; tubulovillous and villous adenomas were found in $7,1 \%$ of polyps (Table 3 ). The overall rate of polyp detection was significantly higher in the conventional group compared to the NBI group (RR 0.75, 95\% CI 0.60 to 0.96 ). Significant differences were also found in the rate of hyperplastic (RR $0.52,95 \%$ CI 0.32 to 0.85 ; p $=0.009$ ) and tubulovillous polyps (RR $0.11,95 \% 0.01$ to $0.87 ; \mathrm{p}=0.009)$. However, no significant differences were found in the mean number of polyps, the rate of polyps measuring less than $5 \mathrm{~mm}$ or the mean time to find the first polyp (Table 2).

Of the adenomas, $9 \%$ were high-grade, with no significant difference between groups. Two adenocarcinomas were found (one in each group). There were no differences between the different examiners in the rate of detection of adenomatous and hyperplastic polyps. No serious adverse events were reported among groups during the procedure.

\section{Systematic Review of the current evidence}

A total of 167 citations were identified from the diverse sources of information (Figure 2). Of the sixteen potentially RCTs screened [19-34], we excluded nine references because they were nonrandomized, they focused on predicting colon polyp histology, or they used other devices. Finally, seven RCTs meet the inclusion criteria [19-21,23,25-27] one of which was published as an abstract [27]. Characteristics of RCTs included in the meta-analysis are described in Table 4. One study was judged as having low risk of bias [21] and six RCTs were judged as having unclear risk of bias because the description of the method used to generate to conceal the allocation was unclear $[19,20,23,27]$; only one evaluator performed all the colonoscopies [25]; inadequate distribution of the NBI

Table 1 Baseline characteristics of patients and colonoscopy performance

\begin{tabular}{|c|c|c|c|}
\hline Parameter & NBI group $(n=241)$ & Conventional group $(n=241)$ & Significance $(p)$ \\
\hline Age (years) & 57.36 (SD 12.07) & 59.29 (SD 12.91) & Ns \\
\hline Gender M/F & $86 / 155$ & $95 / 146$ & Ns \\
\hline Weight (kg) & 66.73 (SD 12.99) & 66.43 (SD 12.45) & Ns \\
\hline Height $(\mathrm{cm})$ & 163.49 (SD 11.37) & 163.11 (SD 8.57) & Ns \\
\hline Total examination time $(\mathrm{min})^{*}$ & 9.21 (SD 3.08) & 9.22 (SD 3.58) & Ns \\
\hline Previous colonoscopy & $94(39.0 \%)$ & $98(40.7 \%)$ & Ns \\
\hline \multicolumn{4}{|l|}{ Indication: } \\
\hline Screening & $42(17.4 \%)$ & $37(15.4 \%)$ & Ns \\
\hline Surveillance & $22(9.1 \%)$ & $18(7.4 \%)$ & Ns \\
\hline Diagnostic & $177(73.5 \%)$ & $186(77.2 \%)$ & Ns \\
\hline \multicolumn{4}{|l|}{ Last colonoscopy (years) } \\
\hline 1 to 3 & 50 & 51 & Ns \\
\hline 3 to 5 & 25 & 26 & Ns \\
\hline 5 to 10 & 11 & 11 & Ns \\
\hline$>10$ & 8 & 10 & Ns \\
\hline Previous polyp resection & $26(10.8 \%)$ & $19(7.9 \%)$ & Ns \\
\hline Familial history of colorectal cancer & $44(18.3 \%)$ & $36(14.9 \%)$ & Ns \\
\hline Excellent/good bowel preparation & $167(69.3 \%)$ & $162(67.5 \%)$ & Ns \\
\hline
\end{tabular}

*Not including polypectomy time. 
Table 2 Main findings from the comparison between narrow-band imaging group and conventional group

\begin{tabular}{|c|c|c|c|c|}
\hline Outcome & NBI group $(n=241)$ & Conventional group $(n=241)$ & Measurement of the intervention effect* & Significance $(p)$ \\
\hline Total number of polyps (visual inspections) & 77 & 102 & RR 0.75 (0.60 to 0.96$)$ & 0.02 \\
\hline Proportion of patients with at least one polyp & $50(20.8 \%)$ & $60(24.9 \%)$ & RR 0.83 (0.60 to 1.16) & Ns \\
\hline Mean number of polyps & 0.32 (SD 0.73) & 0.42 (SD 0.93) & MD $-0.1(-0.25$ to 0.05$)$ & Ns \\
\hline Rate of polyp $\leq 5 \mathrm{~mm}$ & $51(21.2 \%)$ & $62(25.7 \%)$ & RR 0.82 (0.59 to 1.14$)$ & Ns \\
\hline Mean time to find the first polyp (seconds) & 230.8 (SD 227.20) & 220.81 (SD 233.93) & MD $10.80(-30.27$ to 51.87$)$ & Ns \\
\hline
\end{tabular}

* Rate ratio (RR) and $95 \% \mathrm{Cl}$ or mean difference (MD) and $95 \% \mathrm{Cl}$. 
Table 3 Histological characteristic of polyps detected in the narrow-band imaging group and conventional group on a per-polyp basis Outcomes NBI group $(n=241) \quad$ Conventional group $(n=241) \quad$ Measurement of the intervention effect*

(Number of polyps by histological category)
Outcomes

\begin{tabular}{llll}
\hline Tubular adenoma or adenomatous polyp & 46 & 47 & $0.98(0.68$ to 1.41$)$ \\
\hline Hyperplastic polyps & 22 & 42 & $0.52(0.32$ to 0.85$)$ \\
\hline Villous adenoma & 1 & 1 & $1.00(0.06$ to 15.90$)$ \\
\hline Tubulovillous adenoma & 1 & 1 & 0.009 \\
\hline Adenocarcinoma & 1 & 1 & $0.11(0.01$ to 0.87$)$ \\
\hline Other type of lesions & 2 & 1 & $1.00(0.06$ to 15.90$)$ \\
\hline Total number of polyps & 70 & $2(0.18$ to 21.91$)$ \\
\hline Total number of lesions & 73 & 99 & 0.04 \\
\hline
\end{tabular}

* Rate ratio (RR) and $95 \% \mathrm{Cl}$ or mean difference (MD) and $95 \% \mathrm{Cl}$. 

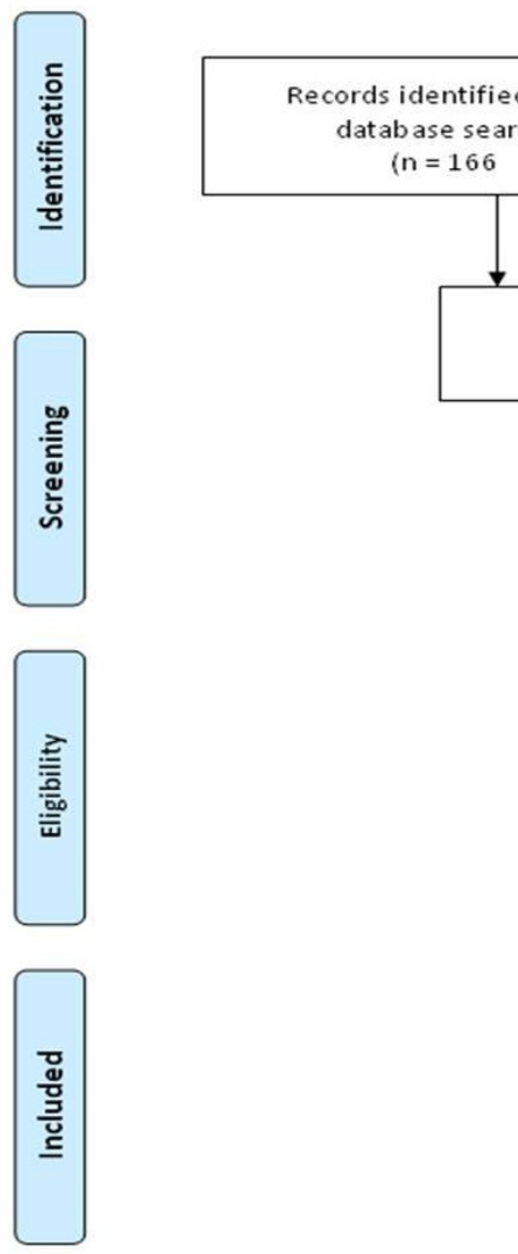

Records after duplicates removed

$(n=121)$
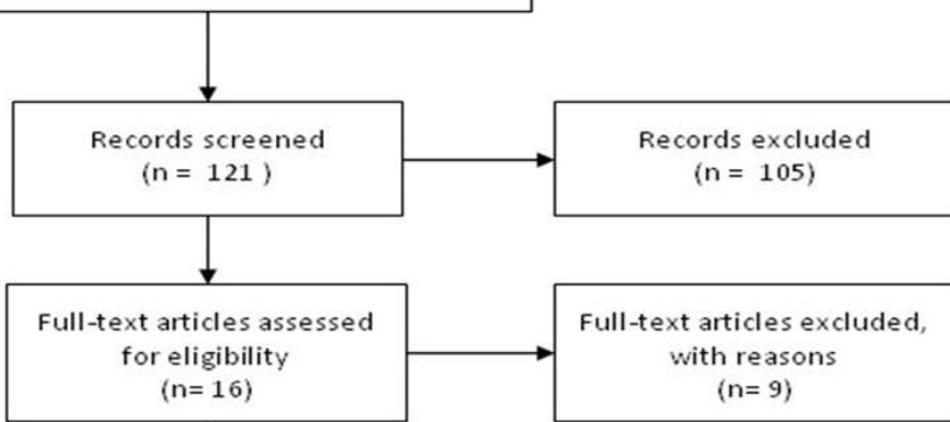

Figure 2 Flow diagram of included and analysed randomized controlled trials

procedure among all participating endoscopists [26]; and a possible learning effect from the NBI during the initial phase of the trial [19]. Only in one RCT each patient underwent back-to-back colonoscopy [21]. The primary outcomes of interest were frequently reported incompletely and we had to impute standard deviations in four studies [19,21,26,27].

A meta-analysis of studies (including diagnostic, surveillance and/or screening colonoscopies) is showed in Table 5. No significant differences were found among groups in the mean number of polyps, the mean number of adenomas (Figure 3), and the rates of patients with al least one polyp or one adenoma (Figure 4). We performed a sensitive analysis comparing those studies that used Lucera or Exera II systems. Significant differences favoring the NBI system in the mean number of polyps (2 RCT, 457 participants; WMD
$-0.3995 \%$ CI -0.62 to -0.16 ; I2 $0 \%)$ and the mean number of adenomas ( $2 \mathrm{RCT}, 457$ participants; WMD $-0.2295 \%$ CI -0.41 to -0.04 ; I2 2\%) were found when pooling data from RCTs that used the Lucera system [26,27].

No serious adverse events were reported. Taken into account that we only found eight RCTs, funnel plots for assessing publication bias was not performed.

\section{Discussion}

\section{Main findings}

According to our findings, the polyp detection rate per patient by visual inspection was significantly higher in the conventional colonoscopy group compared to the NBI group. In addition, significant differences favoring the conventional colonoscopy group were also found for some types of histological examination polyps 
Table 4 Characteristics of included studies in the meta-analysis

\begin{tabular}{|c|c|c|c|c|c|}
\hline Study & Methods & Participants & Interventions & $\begin{array}{l}\text { Primary } \\
\text { Outcomes }\end{array}$ & $\begin{array}{l}\text { Risk of } \\
\text { bias* }\end{array}$ \\
\hline Adler 2009 & $\begin{array}{l}\text { Open-label, } \\
\text { prospective, } \\
\text { randomized, } \\
\text { controlled, } \\
\text { multicenter trial }\end{array}$ & $\begin{array}{l}1256 \text { patients, mean age, } 64.4 \text { years } \\
\text { (range } 31-87 \text { y) undergoing screening } \\
\text { colonoscopy }\end{array}$ & $\begin{array}{l}\text { Wideangle colonoscopy using either } \\
\text { conventional high-resolution imaging or } \\
\text { NBI during instrument withdrawal (6 } \\
\text { endoscopists). Exera II system. }\end{array}$ & $\begin{array}{l}\text { Number of } \\
\text { adenomas/ } \\
\text { number of } \\
\text { patients examined }\end{array}$ & Unclear \\
\hline Adler 2008 & $\begin{array}{l}\text { Open-label, } \\
\text { prospective, } \\
\text { randomized, } \\
\text { controlled trial }\end{array}$ & $\begin{array}{l}401 \text { patients with a mean age of } 59.4 \\
\text { years (SD 13.4) undergoing diagnostic } \\
\text { colonoscopy }\end{array}$ & $\begin{array}{l}\text { Wideangle colonoscopy using either } \\
\text { conventional high-resolution imaging or } \\
\text { NBI during instrument withdrawal (7 } \\
\text { endoscopists). Exera II system. }\end{array}$ & $\begin{array}{l}\text { Adenoma } \\
\text { detection rate }\end{array}$ & Unclear \\
\hline $\begin{array}{l}\text { East } 2009 \\
\text { (abstract) }\end{array}$ & $\begin{array}{l}\text { Open-label, } \\
\text { prospective, } \\
\text { randomized, } \\
\text { controlled trial }\end{array}$ & $\begin{array}{l}214 \text { high risk adenomas patients with a } \\
\text { median age of } 65 \text { and } 66 \text { years in the } \\
\text { NBI and conventional group } \\
\text { respectively }\end{array}$ & $\begin{array}{l}\text { Examination with NBI or white light (WLE), } \\
\text { with high definition (HDTV) colonoscopes } \\
\text { ( } 3 \text { endoscopists). Lucera system. }\end{array}$ & $\begin{array}{l}\text { The number of } \\
\text { patients with at } \\
\text { least one } \\
\text { adenoma } \\
\text { detected. }\end{array}$ & Unclear \\
\hline Inoue 2008 & $\begin{array}{l}\text { Open-label, } \\
\text { prospective, } \\
\text { randomized, } \\
\text { controlled trial }\end{array}$ & $\begin{array}{l}243 \text { patients (NBI mean age, } 61.1 \text { SD } \\
\text { 13.5; conventional mean age } 62.9 \text { SD } \\
\text { 11.3) undergoing surveillance or } \\
\text { diagnostic colonoscopy }\end{array}$ & $\begin{array}{l}\text { Colonoscopy using either conventional } \\
\text { high-resolution imaging or NBI during } \\
\text { instrument withdrawal ( } 6 \text { endoscopists). } \\
\text { Lucera system. }\end{array}$ & $\begin{array}{l}\text { Mean number of } \\
\text { adenomas per } \\
\text { patient }\end{array}$ & Unclear \\
\hline $\begin{array}{l}\text { Kaltenbach } \\
2008\end{array}$ & $\begin{array}{l}\text { Open-label, } \\
\text { prospective, } \\
\text { randomized, } \\
\text { controlled trial }\end{array}$ & $\begin{array}{l}276 \text { patients with a mean age of } 64 \\
\text { (SD 10) years (range } 31 \text { to } 89 \text { ), } \\
\text { undergoing screening, surveillance or } \\
\text { diagnostic colonoscopy }\end{array}$ & $\begin{array}{l}\text { Wideangle colonoscopy using either } \\
\text { conventional high-resolution imaging or } \\
\text { NBI ( } 6 \text { endoscopists); back-to-back } \\
\text { colonoscopy by the same endoscopist. } \\
\text { Exera II system. }\end{array}$ & $\begin{array}{l}\text { Neoplasm miss } \\
\text { rate. }\end{array}$ & Low \\
\hline Paggi 2009 & $\begin{array}{l}\text { Open-label, } \\
\text { prospective, } \\
\text { randomized, } \\
\text { controlled trial }\end{array}$ & $\begin{array}{l}211 \text { patients (from } 50 \text { to } 69 \text { years) with } \\
\text { positive immunologic fecal occult } \\
\text { blood tests }\end{array}$ & $\begin{array}{l}\text { Colonoscopy withdrawal in white light } \\
\text { versus NBI ( } 6 \text { endoscopists). Exera II system. }\end{array}$ & $\begin{array}{l}\text { The detection } \\
\text { rate of adenoma }\end{array}$ & Unclear \\
\hline Rex 2007 & $\begin{array}{l}\text { Open-label, } \\
\text { prospective, } \\
\text { randomized, } \\
\text { controlled trial }\end{array}$ & $\begin{array}{l}434 \text { patients aged } 50 \text { years or older } \\
\text { undergoing screening or surveillance } \\
\text { colonoscopy }\end{array}$ & $\begin{array}{l}\text { Colonoscopy withdrawal in white light } \\
\text { versus NBI (only one endoscopist; high } \\
\text { definition monitors were used). Exera II } \\
\text { system. }\end{array}$ & $\begin{array}{l}\text { Number of } \\
\text { adenomas }\end{array}$ & Unclear \\
\hline $\begin{array}{l}\text { Sabbagh } \\
2011\end{array}$ & $\begin{array}{l}\text { Open-label, } \\
\text { prospective, } \\
\text { randomized, } \\
\text { controlled, } \\
\text { multicenter trial }\end{array}$ & $\begin{array}{l}482 \text { patients with a mean age of } 58.3 \\
\text { (SD 12.9) undergoing screening, } \\
\text { surveillance or diagnostic colonoscopy }\end{array}$ & $\begin{array}{l}\text { Wideangle colonoscopy using either } \\
\text { conventional high-resolution imaging or } \\
\text { NBI ( } 3 \text { endoscopists). Exera II system. }\end{array}$ & $\begin{array}{l}\text { Mean number of } \\
\text { adenomas }\end{array}$ & \\
\hline
\end{tabular}

*The judgment for each entry involves answering a question, with answers "Yes" indicating low risk of bias, "No" indicating high risk of bias, and "Unclear" indicating either lack of information or uncertainty over the potential for bias

(hyperplastic polyps and tubulovillous adenoma). However, the adenoma detection rate was similar in both groups.

Although meta-analysis of RCTs showed no significant difference for pre-specified primary outcomes, individual studies reported diverse findings [19-28]. Statistical heterogeneity may be explained by difference in the prevalence of polyps and adenomas in the population, the indication for colonoscopy (screening, surveillance and/ or diagnostic), the age of the included population, and the examiner's experience among others. Findings of our review update those of a previous systematic review that included three RCTs concerning the detection of colorectal adenomas [36].

Only two RCTs found a significant difference in the mean rate of adenomas favouring the NBI group [21,26]. One RCT, which included 243 patients, found a significant difference in the rate of adenoma detection favoring the
NBI group (22\% vs. $14 \%$ ), including the subgroups of patients having polyps measuring less than $5 \mathrm{~mm}$. The authors of the study recommended the routine use of the NBI system for surveillance of diminutive adenomas [26]. Another study [21] found that the NBI system significantly increased the total number of adenomas detected as well as the number of diminutive adenomas in the distal colon [21]; however the rate of missed lesions between the NBI and conventional group was similar. Another RCT found that the number of diminutive $(<5 \mathrm{~mm})$ adenomas was significantly higher in the NBI group [26]. One RCT reported a significantly higher detection in the mean number of flat adenomas in the NBI group [27], one study reported the opposite [20] and two RCTs did not find any significant difference $[23,25]$.

In our study, colonoscopies were performed by experienced examiners in both techniques and included diagnostic and screening colonoscopies from two different 
Table 5 Meta-analysis of studies comparing conventional colonoscopy to NBI system

\begin{tabular}{|c|c|c|c|c|c|}
\hline Study (Year) & Outcome & Conventional colonoscopy (N) & NBI system (N) & $\mathrm{RR}^{*} \mathrm{WMD}^{* *}(95 \% \mathrm{Cl})$ & Heterogeneity (I2) $\S$ \\
\hline $\begin{array}{l}\text { Adler } 2009 \\
\text { East } 2009 \\
\text { Inoue } 2008 \\
\text { Kaltenbach } 2008 \\
\text { Sabbagh } 2011\end{array}$ & Mean number of polyps & 1241 & 1238 & WMD $-0.07(-0.21$ to 0.07$)$ & $68 \%$ \\
\hline $\begin{array}{l}\text { Adler } 2009 \\
\text { Adler } 2008 \\
\text { East } 2009 \\
\text { Inoue } 2008 \\
\text { Kaltenbach } 2008 \\
\text { Paggi } 2009 \\
\text { Rex 2007 } \\
\text { Sabbagh } 2011\end{array}$ & Mean number of adenomas & 1768 & 1749 & WMD -0.08 (-0.17 to 0.01$)$ & $62 \%$ \\
\hline $\begin{array}{l}\text { Adler } 2009 \\
\text { Adler } 2008 \\
\text { Inoue } 2008 \\
\text { Kaltenbach } 2008 \\
\text { Sabbagh } 2011\end{array}$ & Rate of patients with al least one polyp & 1336 & 1330 & RR 0.90 (0.73 to 1.11$)$ & $70 \%$ \\
\hline $\begin{array}{l}\text { Adler } 2009 \\
\text { Adler } 2008 \\
\text { East } 2009 \\
\text { Inoue } 2008 \\
\text { Kaltenbach } 2008 \\
\text { Paggi } 2009 \\
\text { Rex 2007 } \\
\text { Sabbagh } 2011\end{array}$ & Rate of patients with at least one adenoma & 1763 & 1749 & RR $0.96(0,88$ to 1.04$)$ & $0 \%$ \\
\hline $\begin{array}{l}\text { Adler } 2009 \\
\text { Adler } 2008 \\
\text { Paggi } 2009 \\
\text { Sabbagh } 2011\end{array}$ & Rate of patients with carcinoma & 1181 & 1169 & RR 1.20 (0.58 to 2.47) & $0 \%$ \\
\hline
\end{tabular}

*Relative Risk and 95\% confidence intervals (Cl) for dichotomous outcomes were calculated by the Mantel-Haenszel fixed-effects model when $12<50 \%$. Relative Risk and $95 \%$ confidence intervals (Cl) for dichotomous outcomes were calculated by the Mantel-Haenszel random-effects model when $12>50 \%$.

**Mean difference and $95 \%$ confidence intervals (Cl) for continuous outcomes were calculated using the inverse variance and the fixed-effects model when $12<50 \%$. Mean difference and $95 \%$ confidence intervals (CI) for continuous outcomes were calculated using the inverse variance and the random-effects model when $12>50 \%$.

$\S$ Low, moderate, and high levels of heterogeneity approximately correspond to 12 values of $25 \%, 50 \%$ and $75 \%$, respectively [35]. 


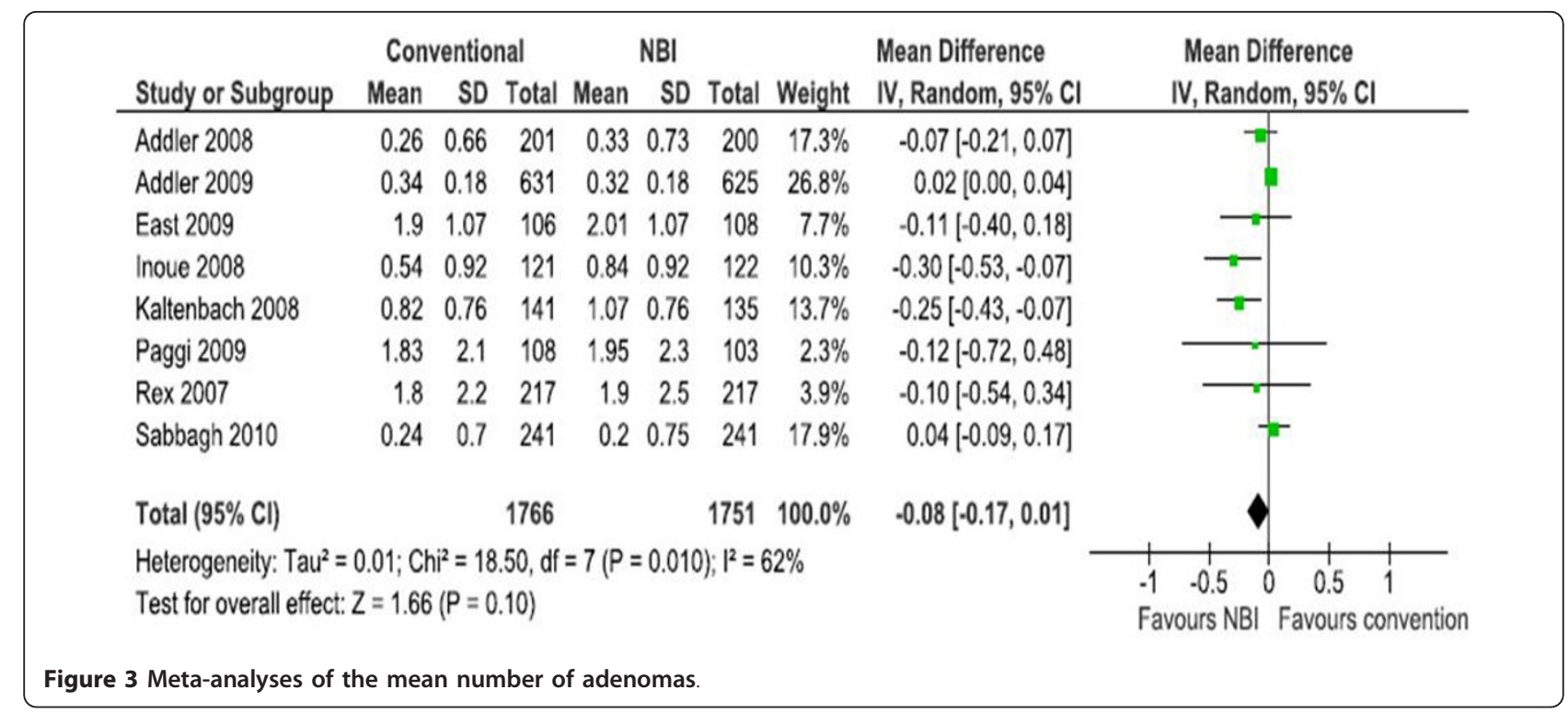

institutions. Adenoma rates in larger colonoscopy trials vary widely. The overall detection rate of polyps and adenomas by histological examination were $35.1 \%$ and $22 \%$ respectively, which is similar to the rates reported in other studies [20,37-40]. However some RCTs found higher rates of polyps and adenomas; the difference can be explained by heterogeneous included population. The lower detection rate in our study may be due to the withdrawal time but also to the lower prevalence in our population. A number of published studies have evaluated the prevalence of polyps and adenomas in Colombia. Overall, the prevalence of colonic adenomas is lower when compared with rates reported in other regions [41-44]. In addition, around one third of patients in our RCT had already had a colonoscopy. Although differences in polyp frequency between screening and diagnostic colonoscopy have been reported, some studies have found similar rates [40]. Additionally, no differences were found in primary outcomes between colonoscopies performed in the two

\begin{tabular}{|c|c|c|c|c|c|c|c|}
\hline \multirow[b]{2}{*}{ Study or Subgroup } & \multicolumn{2}{|c|}{ Conventional } & \multicolumn{2}{|l|}{$\mathrm{NBI}$} & \multirow[b]{2}{*}{ Weight } & \multirow{2}{*}{$\begin{array}{l}\text { Risk Ratio } \\
\text { M-H, Fixed, } 95 \% \mathrm{Cl}\end{array}$} & \multirow{2}{*}{$\begin{array}{c}\text { Risk Ratio } \\
\mathrm{M} \cdot \mathrm{H}, \text { Fixed, } 95 \% \mathrm{Cl}\end{array}$} \\
\hline & Events & Total & Events & Total & & & \\
\hline Addler 2008 & 33 & 198 & 45 & 198 & $7.2 \%$ & $0.73[0.49,1.10]$ & . \\
\hline Addler 2009 & 137 & 631 & 140 & 625 & $22.6 \%$ & $0.97[0.79,1.19]$ & \\
\hline East 2009 & 71 & 106 & 79 & 108 & $12.6 \%$ & $0.92[0.77,1.09]$ & $\rightarrow$ \\
\hline Inoue 2008 & 41 & 121 & 51 & 122 & $8.2 \%$ & $0.81[0.59,1.12]$ & \\
\hline Kaltenbach 2008 & 66 & 141 & 69 & 135 & $11.3 \%$ & $0.92[0.72,1.17]$ & 7 \\
\hline Paggi 2009 & 63 & 108 & 59 & 103 & $9.7 \%$ & $1.02[0.81,1.28]$ & \\
\hline $\operatorname{Rex} 2007$ & 145 & 217 & 140 & 217 & $22.5 \%$ & $1.04[0.90,1.19]$ & \\
\hline Sabbagh 2010 & 41 & 241 & 36 & 241 & $5.8 \%$ & $1.14[0.76,1.72]$ & \\
\hline Total $(95 \% \mathrm{Cl})$ & & 1763 & & 1749 & $100.0 \%$ & $0.96[0.88,1.04]$ & \\
\hline Total events & 597 & & 619 & & & & \\
\hline $\begin{array}{l}\text { Heterogeneity: } \mathrm{Ch}^{2}= \\
\text { Test for overall effect: }\end{array}$ & $\begin{array}{l}53, \mathrm{df}=7 \\
Z=1.06(F\end{array}$ & $\begin{array}{l}(P=0.6 \\
=0.29)\end{array}$ & $62) ; 1^{2}=09$ & & & & 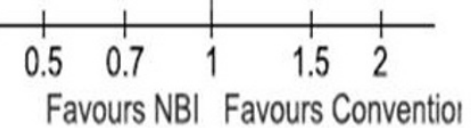 \\
\hline
\end{tabular}


different clinics, or when different periods of time were compared (first 241 colonoscopies vs. last 241 colonoscopies).

\section{Limitations of the study}

The findings of this RCT have some limitations, mostly due to the lack of tandem colonoscopy in both groups. Difference in the overall rate of polyps could have been due to selection bias (patients with more polyps could have been included in the conventional group by chance). However, we found no significant differences among participants in the baseline characteristics and the colonoscopy performance; we included a significant number of patients and we concealed the allocation of patients to minimize any possible bias. Our data shows that the white-light group had $20.8 \%$ higher detection rate of adenomas than did the NBI group. As both groups had similar withdrawal time, the white-light group could have had better mucosal visualization during the withdrawal phase compared to that of the NBI group (the darkening of the image associated with the use of NBI). This may have lead to the finding of significantly greater number of polyps found in the white-light group.

In addition, the fact that bowel preparation was not excellent in one third of patients may have contributed to the poorer performance of the NBI visualization. As screening colonoscopy is not usually recommended in our country in people above 50 years of age with average risk, we had an important proportion of diagnostic colonoscopies.

Concerning the review, we pooled data from studies that included heterogeneous populations and indications. The use of varied endoscopic systems as well as differences in colon preparation of participants between studies may have had some impact on findings. Uraoka et al noticed that significant differences in the detection of adenomas where related to the type of endoscopic video system (either the sequential LUCERA series or the simultaneous EXERA-II series). They found that most positive studies used the LUCERA system while all of the negative studies used the EXERA-II system [45]. Although pooled estimates from two RCTs [26,27] support the use of LUCERA series, both studies where judged as having unclear risk of bias. More research is still needed to determine the efficacy of different NBI system settings for screening and surveillance colonoscopies, particularly to enhance the detection rate for flat adenomatous lesions [45].

Finally, there were differences in the report of flat or non-polypoid type neoplasm among studies which did not permit further pooled analysis.

\section{Conclusion}

This RCT in two homogeneous practices did not show any objective advantage of the NBI technique over the conventional colonoscopy in terms of improved adenoma detection rate. Pooled estimated of published RCT showed no benefits of the NBI system over the conventional colonoscopy in terms of the mean number of polyps and the mean number of adenomas identified.

\section{Appendix 1. Search strategy for PUBMED}

((randomized controlled trial [pt] OR controlled clinical trial [pt] OR randomized [tiab] OR placebo [tiab] OR drug therapy [sh] OR randomly [tiab] OR trial [tiab] OR groups [tiab]) NOT (animals [mh] NOT (humans [mh] AND animals [mh]))) AND (Colonoscopy [mh] OR colonosco* $[\mathrm{tw}]$ OR (intestin* endoscop* [tw])) AND (narrow band [tw] OR NBI [tw])

\section{Acknowledgements}

We wish to acknowledge the pathology department of the Clínica Reina Sofía and the Clínica Colombia for their support.

Funding

No direct funding was received for this study. The authors were personally salaried by their institutions during the period of writing (though no specific salary was set aside or given for the writing of this paper)

\section{Author details}

${ }^{1}$ Gastroenterology Department, Clínica Reina Sofía, Sanitas University Foundation, Bogota, Colombia. ${ }^{2}$ Research Institute, Sanitas University Foundation, Bogota, Colombia. ${ }^{3}$ Gastroenterology Department, Clínica Colombia, Bogota, Colombia. ${ }^{4}$ General Practice Department, Clínica Reina Sofía, Bogota, Colombia.

\section{Authors' contributions}

LCS and DA conceived the study and participated in the study coordination. All authors participated in the study design, data analysis and contributed to preparing the manuscript, and read and approved the final manuscript.

\section{Declaration of competing interests}

The authors declare that they have no competing interests.

Received: 16 February 2010 Accepted: 23 September 2011

Published: 23 September 2011

\section{References}

1. U.S. Preventive Services Task Force: Screening for colorectal cancer: U.S. Preventive Services Task Force recommendation statement. Ann Intern Med 2008, 149(9):627-37.

2. Whitlock EP, Lin JS, Liles E, Beil TL, Fu R, O'Connor E, Thompson RN, Cardenas T: Screening for colorectal cancer: an updated systematic review. Evidence Synthesis No. 65, Part 1. AHRQ publication no. 0805124-EF-1. Rockville, MD: Agency for Healthcare Research and Quality; 2008.

3. Whitlock E, Lin JS, Liles E, Beil TL, Fu R: Screening for colorectal cancer: a targeted systematic review for the U.S. Preventive Services Task Force. Ann Intern Med 2008, 149.

4. Robertson DJ, Greenberg ER, Beach M, Sandler RS, Ahnen D, Haile RW, Burke CA, Snover DC, Bresalier RS, McKeown-Eyssen G, Mandel JS, Bond JH, Van Stolk RU, Summers RW, Rothstein R, Church TR, Cole BF, Byers T, Mott $L$, Baron JA: Colorectal cancer in patients under close colonoscopic surveillance. Gastroenterology 2005, 129:34-41.

5. Winawer SJ, Zauber AG, Ho MN, O'Brien MJ, Gottlieb LS, Sternberg SS, Waye JD, Schapiro M, Bond JH, Panish JF, Ackroyd F, Shike M, Kurtz RC, Hornsby-Lewis L, Gerdes H, Stewart ET, and the National Polyp Study Workgroup: The National Polyp Study Workgroup. Prevention of Colorectal Cancer by Colonoscopic Polypectomy. N Engl J Med 1993, 329:1977-81. 
6. Bensen S, Mott LA, Dain B, Rothstein R, Baron J: The colonoscopic miss rate and true one-year recurrence of colorectal neoplastic polyps. Polyp Prevention Study Group. Am J Gastroenterol 1999, 94:194-9.

7. van Rijn JC, Reitsma JB, Stoker J, Bossuyt PM, van Deventer SJ, Dekker E: Polyp miss rate determined by tandem colonoscopy: a systematic review. Am J Gastroenterol 2006, 101(2):343-50.

8. Heresbach D, Barrioz T, Lapalus MG, Coumaros D, Bauret P, Potier P, Sautereau D, Boustière C, Grimaud JC, Barthélémy C, Sée J, Serraj I, D'Halluin PN, Branger B, Ponchon T: Miss rate for colorectal neoplastic polyps: a prospective multicenter study of back-to-back video colonoscopies. Endoscopy 2008, 40(4):284-90.

9. Postic G, Lewin D, Bickerstaff C, Wallace MB: Colonoscopic miss rates determined by direct comparison of colonoscopy with colon resection specimens. Am J Gastroenterol 2002, 97(12):3182-5.

10. Simmons DT, Harewood GC, Baron TH, Petersen BT, Wang KK, BoydEnders F, Ott BJ: Impact of endoscopist withdrawal speed on polyp yield: implications for optimal colonoscopy withdrawal time. Aliment Pharmacol Ther 2006, 15;24(6):965-71.

11. Morini S, Hassan C, Zullo A, Lorenzetti R, de Matthaeis M, Stella F, Campo SM: Detection of colonic polyps according to insertion/ withdrawal phases of colonoscopy. Int J Colorectal Dis 2009, 24(5):527-30.

12. Pickhardt PJ, Nugent PA, Mysliwiec PA, Choi JR, Schindler WR: Location of adenomas missed by optical colonoscopy. Ann Intern Med 2004, 7;141(5):352-9.

13. Huh KC, Rex DK: Advances in colonoscope technique and technology. Rev Gastroenterol Disord 2008, Fall;8(4):223-32.

14. Gono K, Obi T, Yamaguchi M, Ohyama N, Machida H, Sano Y, Yoshida S, Hamamoto $Y$, Endo T: Appearance of enhanced tissue features in narrow-band endoscopic imaging. J Biomed Opt 2004, 9:568-77.

15. Rastogi A, Bansal A, Wani S, Callahan P, Pandya P, Mathur S, Sharma P: Does Narrow Band Imaging (NBI) Colonoscopy Increase the Detection Rate of Colon Polyps? - A Pilot Feasibility Study Gastrointestinal Endoscopy. 2007, 65(5):AB259-AB259.

16. Sano $Y$, Kobayashi M, Hamamoto $Y$ : New diagnostic method based on color imaging using narrow-band imaging (NBI) system for gastrointestinal tract. Gastrointest Endosc 2001, 53:AB125.

17. Machida H, Sano Y, Hamamoto Y, Muto M, Kozu T, Tajiri H, Yoshida S: Narrow-band imaging for differential diagnosis of colorectal mucosal lesions: a pilot study. Endoscopy 2004, 36:1094-8.

18. Sano Y, Tajiri H, Shigeaki A: Optical/Digital Chromoendoscopy during colonoscopy using Narrow-Banding Imaging system Digestive Endoscopy. 2005, 17(Suppl):S43-S48.

19. Adler A, Pohl H, Papanikolaou IS, Abou-Rebyeh H, Schachschal G, VeltzkeSchlieker $\mathrm{W}$ : A prospective randomised study on narrow-band imaging versus conventional colonoscopy for adenoma detection: does narrowband imaging induce a learning effect? Gut 2008, 57(1):59-64.

20. Adler A, Aschenbeck J, Yenerim T, Mayr M, Aminalai A, Drossel R: Narrowband versus white-light high definition television endoscopic imaging for screening colonoscopy: a prospective randomized trial. Gastroenterology 2009, 136(2):410-6.e1

21. Kaltenbach T, Friedland S, Soetikno R: A randomised tandem colonoscopy trial of narrow band imaging versus white light examination to compare neoplasia miss rates. Gut 2008, 57(10):1406-12.

22. Rastogi A, Bansal A, Wani S, Callahan P, Pandya P, Mathur S, Sharma P: Does Narrow Band Imaging (NBI) Colonoscopy Increase the Detection Rate of Colon Polyps? - A Pilot Feasibility Study Gastrointestinal Endoscopy. 2007, 65(5):AB259-AB259.

23. Paggi S, Radaelli F, Amato A, Meucci G, Mandelli G, Imperiali G, Spinzi G, Terreni N, Lenoci N, Terruzzi V: The Impact of Narrow Band Imaging in Screening Colonoscopy: A Randomized Controlled Trial. Clin Gastroenterol Hepatol 2009, 7(10):1049-54.

24. Rastogi A, Bansal A, Wani S, Callahan P, McGregor DH, Cherian R, Sharma P: Narrow-band imaging colonoscopy-a pilot feasibility study for the detection of polyps and correlation of surface patterns with polyp histologic diagnosis. Gastrointest Endosc 2008, 67(2):280-6.

25. Rex DK, Helbiig CC: High Yield of small and flat adenomas with high definition colonoscopes using either white light or narrow band imaging. Gastroenterology 2007, 133:42-47.

26. Inoue T, Murano M, Murano N, Kuramoto T, Kawakami K, Abe Y, Morita E, Toshina K, Hoshiro H, Egashira Y, Umegaki E, Higuchi K: Comparative study of conventional colonoscopy and pan-colonic narrow -band imaging system in the detection of neoplastic colonic polyps: a randomized controlled trial. J Gastroenterol 2008, 43:45-50.

27. East JE, Suzuki N, Guenther T, Palmer N, Stavrinidis M, Ignjatovic A, Saunders BP: Narrow band imaging (NBI) for adenoma detection in high risk patients: a randomised, controlled trial. Endoscopy 2009, 41(Suppl 1): A223.

28. Uraoka T, Saito Y, Matsuda T, Sano Y, Ikehara H, Mashimo Y, Kikuchi T, Saito D, Saito H: Detectability of colorectal neoplastic lesions using a narrow-band imaging system: a pilot study. J Gastroenterol Hepatol 2008, 23(12):1810-5.

29. Dekker E, van den Broek FJ, Reitsma JB, Hardwick JC, Offerhaus GJ, van Deventer SJ, Hommes DW, Fockens P: Narrow-band imaging compared with conventional colonoscopy for the detection of dysplasia in patients with longstanding ulcerative colitis. Gut 2007, 56(3):373-9.

30. Dekker E, van den Broek FJ, Reitsma JB, Hardwick JC, Offerhaus GJ, van Deventer SJ, Hommes DW, Fockens P: Narrow-band imaging compared with conventional colonoscopy for the detection of dysplasia in patients with longstanding ulcerative colitis. Endoscopy 2007, 39(3):216-21.

31. Rastogi A, Bansal A, Wani S, Callahan P, McGregor DH, Cherian R, Sharma P: Narrow-band imaging colonoscopy-a pilot feasibility study for the detection of polyps and correlation of surface patterns with polyp histologic diagnosis. Gastrointest Endosc 2008, 67(2):280-6.

32. Sikka S, Ringold DA, Jonnalagadda S, Banerjee B: Comparison of white light and narrow band high definition images in predicting colon polyp histology, using standard colonoscopes without optical magnification. Endoscopy 2008, 40(10):818-22.

33. East JE, Suzuki N, Bassett P, Stavrinidis M, Thomas HJ, Guenther T, Tekkis PP, Saunders BP: Narrow band imaging with magnification for the characterization of small and diminutive colonic polyps: pit pattern and vascular pattern intensity. Endoscopy 2008, 40(10):811-7.

34. Horiuchi A, Nakayama Y, Kato N, Ichise Y, Kajiyama M, Tanaka N: HoodAssisted Colonoscopy Is More Effective in Detection of Colorectal Adenomas Than Narrow-Band Imaging. Clin Gastroenterol Hepatol 2009.

35. Higgins JPT, Green S, (editors): Cochrane Handbook for Systematic Reviews of Interventions Version 5.0.0 [updated February 2008]. The Cochrane Collaboration 2008 [http://www.cochrane-handbook.org], The Cochrane Collaboration, 2008.

36. van den Broek FJ, Reitsma JB, Curvers WL, Fockens P, Dekker E: Systematic review of narrow-band imaging for the detection and differentiation of neoplastic and nonneoplastic lesions in the colon (with videos). Gastrointest Endosc 2009, 69(1):124-35.

37. Barclay RL, Vicari JJ, Doughty AS, Johanson JF, Greenlaw RL: Colonoscopic withdrawal times and adenoma detection during screening colonoscopy. N Engl J Med 2006, 355:2533-2541.

38. Sieg A, Theilmeier A: Results of coloscopy screening in 2005-an Internetbased documentation. Dtsch Med Wochenschr 2006, 131:379-383.

39. Byeon JS, Yang SK, Kim TI, Kim WH, Lau JY, Leung WK, for the Asia Pacific Working Group for Colorectal Cancer: Colorectal neoplasm in asymptomatic Asians: a prospective multinational multicenter colonoscopy survey. Gastrointest Endosc 2007, 65(7):1015-1022.

40. Adler A, Roll S, Marowski B, Drossel R, Rehs HU, Willich SN, Riese J, Wiedenmann B, Rösch T, Berlin Private-Practice Gastroenterology Working Group: Appropriateness of colonoscopy in the era of colorectal cancer screening: a prospective, multicenter study in a private-practice setting (Berlin Colonoscopy Project 1, BECOP 1). Dis Colon Rectum 2007, 50(10):1628-1638.

41. Mariño G, Arango JH, Hoyos JA, Vallejo JF, Kestemberg A: Pólipos de colon en Cali, Colombia 1995-1996. Correlación de hallazgos endoscópicos e histopatológicos. Rev colomb Gastroenterol 1997, 12(3):151-3.

42. Peñaloza A, Piña R, Reyes P, Murillo O: Pólipos de colon: revisión 1984 a 1989. Rev colomb Gastroenterol 1991, 6(1):13-7.

43. Restrepo C, Correa P, Duque E, Cuello C: Polyps in a low-risk colonic cancer population in Colombia, South America. Dis Colon Rectum 1981, 24(1):29-36.

44. Cardona Villamizar HJ, Otero Regino W, Forero Piñeros EA, Gutiérrez Ceballos O: Significado de los pólipos en colon distal en una población de un país en vía de desarrollo: prevalencia y asociación con neoplasia proximal sincrónica. Rev Col Gastroenterol 2004, 19(4):253-262.

45. Uraoka T, Higashi R, Saito Y, Matsuda T, Yamamoto K: Impact of narrowband imaging in screening colonoscopy Digestive Endoscopy. 2010, 22(Suppl 1):S54-6. 


\section{Pre-publication history}

The pre-publication history for this paper can be accessed here: http://www.biomedcentral.com/1471-230X/11/100/prepub

doi:10.1186/1471-230X-11-100

Cite this article as: Sabbagh et al:: Narrow-band imaging does not

improve detection of colorectal polyps when compared to conventional colonoscopy: a randomized controlled trial and meta-analysis of published studies. BMC Gastroenterology 2011 11:100.

Submit your next manuscript to BioMed Central and take full advantage of:

- Convenient online submission

- Thorough peer review

- No space constraints or color figure charges

- Immediate publication on acceptance

- Inclusion in PubMed, CAS, Scopus and Google Scholar

- Research which is freely available for redistribution

Submit your manuscript at www.biomedcentral.com/submit
C Biomed Central 